\title{
PENGARUH KARAKTERISTIK INFORMASI SISTEM AKUNTANSI MANAJEMEN, KETIDAKPASTIAN LINGKUNGAN, DAN DESENTRALISASI TERHADAP KINERJA MANAJERIAL (STUDI EMPIRIS PADA PERUSAHAAN BUMN DI BANDA ACEH)
}

\author{
Rizka Febrianti*1 ${ }^{1}$, Yulia Fitri ${ }^{* 2}$ \\ ${ }^{1,2}$ Program Studi Akuntansi Fakultas Ekonomi dan Bisnis Universitas Syiah Kuala \\ e-mail: ebi1998@mhs.unsyiah.ac.id ${ }^{* 1}$, yfitri.fekon@ unsyiah.ac.id $^{* 2}$
}

\begin{abstract}
The purpose of this research is to examine the effect of characteristics of management accounting system information, environmental uncertainty, and decentralization on managerial performance. Data collection techniques in this study were collected by distributing questionnaires to 70 managers who had been set as samples in 18 BUMN companies in Banda Aceh. Statistical tests are performed using multiple linear regression analysis with SPSS 20. The results of the study prove that the four characteristics of management accounting information systems (broad scope, timeliness, aggregation, integration), and decentralization have a positive and significant effect on managerial performance. Enviromental uncertainty have a negative and significant effect on managerial performance.
\end{abstract}

Keywords: Broad scope, Timeliness, Aggregation, Integration, Enviromental Uncertainty, Decentralization

\section{Pendahuluan}

Dewasa ini keberadaan BUMN (Badan Usaha Milik Negara) di Indonesia sangat penting bagi pemerintah maupun masyarakat luas. Bagi pemerintah, BUMN adalah salah satu komponen penting dalam hal pembangunan ekonomi dan bagi masyarakat luas, keberadaan BUMN merupakan perusahaan yang menyediakan layanan yang cepat, murah, dan juga efisien (Fajari, 2015). Sebagai salah satu sumber penerimaan negara, BUMN tentunya dituntut harus tetap memperoleh laba sebesar-besarnya. Kenyataannya pada akhir tahun 2017, BUMN mengalami kerugian hingga menyebabkan beberapa perusahaan BUMN mengalami kebangkrutan. Hal ini disebabkan oleh faktor eksternal yang bersifat uncontrollable, dan juga lemahnya daya saing. Kelemahan daya saing bersumber dari antisipasi bisnis karena dinamika lingkungan yang terus berubah, kualitas SDM dan juga pimpinan yang kurang handal, serta terlalu lama dalam proses pengambilan keputusan (https://news.detik.com, 9 Desember 2018). Salah satu cara dalam mengatasi permasalahan ini adalah dengan meningkatkan kinerja manajerial agar kinerja perusahaan meningkat secara keseluruhan.

Kesuksesan suatu perusahaan juga bergantung pada kinerja manajerial, apabila kinerja manajerial mengalami peningkatan, maka secara bersamaan kinerja perusahaan akan ikut meningkat secara keseluruhan. Mengingat semakin kompleksnya perekonomian, maka tidak mudah bagi manajer untuk melakukan operasi perusahaan sesuai dengan perencanaan yang telah di tetapkan (Sulistiyanto, 2005). Kinerja manajerial dapat dipengaruhi oleh berbagai faktor, diantaranya adalah karakteristik ISAM (ISAM), ketidakpastian lingkungan, dan desentralisasi (Damayanti, Sujana, \& Werastuti, 2015).

Kesuksesan suatu perusahaan juga bergantung pada kinerja manajerial, apabila kinerja manajerial mengalami peningkatan, maka secara bersamaan kinerja perusahaan akan ikut meningkat secara keseluruhan. Mengingat semakin kompleksnya perekonomian, maka tidak mudah bagi manajer untuk melakukan operasi perusahaan sesuai dengan perencanaan yang telah di tetapkan (Sulistiyanto, 2005). Kinerja manajerial dapat dipengaruhi oleh berbagai faktor, diantaranya adalah karakteristik Informasi Sistem Akuntansi Manajemen (ISAM), ketidakpastian lingkungan, dan desentralisasi (Damayanti, Sujana, \& Werastuti, 2015). Menurut Soobaroyen dan Poorundersing (2008) dalam (Indriani \& Nadir, 2015), karakteristik merupakan pengukuran untuk kualitas yang andal serta dapat menggambarkan kecanggihan sistem akuntansi manajemen. Perusahaan dalam berbagai jenis usaha 
sedang bersaing secara ketat karena dihadapkan oleh kondisi pertumbuhan ekonomi serta implikasi globalisasi. Hal ini akan menjadi hambatan tersendiri bagi perusahaan bagaimana cara agar terus berkembang dan tetap bertahan di lingkungan bisnis yang mengalami ketidakpastian tinggi. Menurut Miliken (1987) ketidakpastian lingkungan adalah ketidakmampuan individu dalam meramalkan hal yang akan terjadi secara tepat apa yang akan terjadi di lingkungan eksternal perusahaan (Sari, 2014). Ketidakpastian lingkungan adalah kondisi di luar perusahaan yang dapat mempengaruhi operasi perusahaan serta dapat mengganggu fungsi manajemen dalam perencanaan dan pengendalian (Putri, 2014). Apabila keadaan ketidakpastian lingkunan tinggi, maka perencanaan yang telah disusun akan bermasalah, akibat dari ketidakmampuan manajer untuk meramalkan kondisi yang akan terjadi di masa mendatang. Begitu juga dengan fungsi pengendalian yang akan terpengaruh dengan kondisi ketidakpastian yang tinggi, sehingga berakibat terhambatnya pengambilan keputusan manajer (NurAzizah, 2014). Desentralisasi diperlukan sebagai akibat dari kompleksitas kondisi administrasi, serta tanggung jawab dan tanggung jawab manajer, sehingga Anda harus mendelegasikan wewenang kepada manajer tingkat bawah (Gordon \& Miller 1976; letje Nazaruddin, 1998 dalam Fitrianingrum \& Wijayanti, 2011). Dengan begitu perusahaan yang menerapkan desentralisasi akan membantu meringankan beban manajemen yang lebih tinggi (Paylosa, 2014). Pengambilan keputusan yang diserahkan ke manajemen yang lebih rendah akan lebih efektif, karena manajer tersebut yang lebih tahu bagaimana kondisi yang sebenarnya terjadi di dalam lingkupnya.

Damayanti, Sujana, \& Werastuti (2015) melakukan penelitian pada hotel sekabupaten Buleleng, dan menyimpulkan bahwa ketiga variabel yaitu karakteristik ISAM, desentralisasi, dan juga ketidakpastian lingkungan mempunyai pengaruh signifikan positif terhadap kinerja manajerial. Begitu pula dengan penelitian Jayanti \& Widodo (2014) mereka menyimpulkan ketidakpastian lingkungan dan karakteristik ISAM terhadap kinerja para manajer di BUMN di Jawa Timur secara simultan berpengaruh signifikan. Secara parsial, antara karakteristik ISAM dan kinerja manajerial berpengaruh signifikan, akan tetapi secara parsial antara ketidakpastian lingkungan dengan kinerja manajerial tidak memiliki pengaruh yang signifikan. Hasil penelitian lainnya yaitu Sulkiah (2016) menunjukkan adanya pengaruh antara ketidakpastian lingkungan dan lingkup sistem akuntansi manajemen dengan kinerja manajerial pada rumah sakit di Lombok Timur baik secara parsial dan simultan.

Penelitian ini adalah penelitian yang mereplikasi penelitian Damayanti et al. (2015) yang berjudul "Pengaruh karakteristik informasi sistem akuntansi manajemen (SAM), desentralisasi, dan ketidakpastian lingkungan terhadap kinerja manajerial (Studi empiris pada hotel sekabupaten Buleleng)". Penelitian Damayanti et al. (2015) dilakukan pada hotel, sedangkan objek pada penelitian ini yakni BUMN di Kota Banda Aceh. Penelitian Damayanti et al. (2015) hanya melihat pengaruh karakteristik ISAM secara keseluruhan terhadap kinerja manajerial, pada penelitian ini melihat pengaruh masing-masing dari empat karakteristik ISAM terhadap kinerja manajerial.

Setelah memaparkan latar belakang, peneliti tertarik untuk mengajukan penelitian yang diberi judul "Pengaruh Karakteristik Informasi Sistem Akuntansi Manajemen, Ketidakpastian Lingkungan, dan Desentralisasi terhadap Kinerja Manajerial (Studi Empiris Pada Perusahaan BUMN di Banda Aceh)".

\section{Kerangka Teoritis Dan Pengembangan Hipotesis \\ Teori Kinerja Manajerial}

Kinerja merupakan informasi yang disampaikan kepada pihak yang berkepentingan mengenai suatu pencapaian perusahaan serta mengenai dampak positif maupun negatif akibar dari satu keputusan yang telah diambil (Azzumar, Syam, \& Zuraida, 2018). Kinerja perusahaan dan kinerja manajerial merupakan dua jenis kinerja. Menurut Mahoney (1963) dalam Sulistiyanto (2005) kinerja manajerial yaitu kinerja individu anggota perusahaan secara pribadi pada fungsi manajemen yaitu perencanaan, investigasi, koordinasi, evaluasi, supervisi, pengaturan staf, negosiasi dan perwakilan.

Menurut Pasaribu (2009) kinerja manajerial merupakan penilaian teratur terhadap efektif atau tidaknya operasional perusahaan, bagian perusahaan, dan anggotanya yang didasarkan pada target dan ukuran serta kriteria yang sebelumnya sudah ditetapkan. Kinerja manajerial menjadi sangat penting 
karena kinerja perusahaan akan meningkat secara menyeluruh seiring dengan apabila kinerja manajerial meningkat. Kinerja manajerial juga dapat menjadi faktor yang membuat keefektifan perusahaan meningkat. Situasi dan lingkungan yang terus berubah membuat pihak manajemen juga dituntut untuk mengikuti perubahan, jika tidak mengikuti perubahan tersebut maka tujuan perusahaan tidak tercapai keputusan yang diambil tidak akan sesuai (Senduk, Ilat, \& Tirayoh, 2017).

\section{Pengaruh Broad scope terhadap Kinerja Manajerial}

Broad scope menyediakan informasi tentang masalah ekonomi dan juga non ekonomi. Broad scope bisa dikatakan informasi yangbercakupan luas karena menyediakan informasi mengenai lingkungan internal juga lingkungan eksternal perusahaan. Beberapa informasi ekonomi yang berkenaan dengan lingkungan eksternal yaitu total penjualan pasar, pangsa pasar, dan produk nasional bruto. Beberapa informasi non ekonomi yang berkenaan dengan lingkungan eksternal perusahaan yaitu faktor demografi, tindakan pesaing, serta kemajuan teknologi. Berbagai informasi baik bersifat eksternal maupun internal sangat bermanfaat bagi manajer dalam menjalankan tugasnya pada fungsi perencanaan dan juga pengendalian perusahaan.

Dalam menjalankan fungsinya sebagai manajer, diperlukan informasi dari berbagai sumber yang bersifat luas agar fungsi tersebut dapat berjalan dengan baik. Broad scope sangat dibutuhkan oleh manajer karena mampu menyediakan informasi yang bercakupan luas serta lengkap termasuk informasi mengenai aspek ekonomi dan non ekonomi yang telah dijelaskan sebelumnya.

Fitriani (2013), Ernawati (2008), Gusti Ayu \& Lovelly Dwinda Dahen (2014), Sulkiah (2016), Lisa Khairina Putri (2014) telah melakukan penelitian dan membuktikan bahwa adanya pengaruh signifikan dan positif antara karakteristik ISAM broad scope dengan kinerja manajerial. Namun penelitian Fitrianingrum \& Wijayanti (2011) menyatakan interaksi antara broad scope dengan ketidakpastian lingkungan dan kinerja manajerial tidak berpengaruh positif signifikan.

\section{Pengaruh Timeliness terhadap Kinerja Manajerial}

Agar manajer cepat dalam menanggapi tiap-tiap permasalahan yang terjadi, maka informasi yang manajer butuhkan harus disampaikan secara tepat waktu dan juga dapat menghindari agar masalah tersebut tidak semakin memburuk. Timeliness dapat mempengaruhi para manajer untuk mengatasi setiap situasi secara cepat. Penyampaian informasi secara tepat waktu dapat membuat sarana sistem akuntansi manajemen meningkat dalam melakukan pelaporan situasi-situasi yang aktual sehingga dapat membantu dalam memberikan respon terhadap keputusan yang telah diambil secara cepat. Informasi timeliness mencakup frekuensi serta kecepatan dalam pelaporan.

Informasi yang disajikan secara timeliness dapat menjadi hal yang akan dipertimbanngkan dalam pengambilan keputusan sebelum hilang kapasitas informasi tersebut untuk dapat berpengaruh pada keputusan. Chia (1995) dalam (Paylosa, 2014) mengungkapkan bahwa waktu informasi ditunjukkan dengan selisih waktu antara permintaan informasi dengan diterimanya informasi dari sistem akuntansi manajemen kepada pihak yang membutuhkan. Kecepatan seorang manajer dalam melakukan proses pengambilan keputusan akan meningkat seiring semakin cepatnya selisih waktu yang tersedia. Jadi dapat disimpulkan bahwa informasi yang disampaikan secara timeliness dapat memberikan feedback secara cepat terhadap keputusan yang diambil, dengan begitu maka otomatis akan meningkatkan kinerja manajerial.

Beberapa penelitian yang sudah diteliti sebelumnya membuktikan bahwa antara karakteristik ISAM timeliness dengan kinerja manajerial memiliki pengaruh. Fitriani (2013), Ayu \& Dahen (2014), Sulkiah (2016) dalam penelitiannya berpendapat bahwa terdapat pengaruh signifikan dan positif terhadap kinerja manajerial. Kinerja manajerial akan semakin tinggi seiring apabila karakteristik ISAM timeliness juga semakin tinggi.

\section{Pengaruh Aggregation terhadap Kinerja Manajerial}

Informasi yang teragregasi dapat membantu dalam meningkatkan efisiensi dan efektivitas kinerja manajerial, karena informasi yang teragregasi menyajikan informasi secara ringkas tetapi tidak menghilangkan hal-hal penting yang ada sehingga informasi tersebut nilainya tidak berkurang. Salah satu kontribusi yang penting pada proses pengambilan keputusan adalah informasi yang teragregasi secara tepat, karena adanya penghematan penggunaan waktu 
dalam mengevaluasi informasi dibandingkan penggunaan waktu untun mengevaluasi informasi mentah atau tidak teragregasi akan membutuhkan lebih banyak waktu. Informasi yang teragregasi dibutuhkan dalam perusahaan untuk mencegah terjadinya overload informasi (Iselin, 1988) dalam ( Herdiansyah, 2012).

Ayu \& Dahen (2014) dan (Sulkiah, 2016) dalam penelitiannya membuktikan bahwa adanya pengaruh signifikan positif antara karakteristik ISAM aggregation dengan kinerja manajerial. Namun dalam penelitian Fitriani (2013) membuktikan bahwa terdapat pengaruh signifikan negatif antara karakteristik ISAM aggregation dengan kinerja manajerial.

\section{Pengaruh Integration terhadap Kinerja Manajerial}

Informasi integrasi yaitu informasi yang terkoordinasi di subunit antar bagian yang satunya dengan lainnya. Informasi terintegrasi termasuk beberapa aspek target ditentukan ataupun perhitungan aktivitas pada proses interaksi antar sub unit di perusahaan. Perusahaan lebih banyak membutuhkan informasi yang terintegrasi jika semakin banyak bagian didalam sub unit perusahaan. Informasi terintegrasi dapat dijadikan pengawas dalam mengontrol pengambilan keputusan yang bervariasi.

Semua informasi yang didapatkan oleh manajer sebaiknya mempunyai karakter yang bisa menggambarkan kompleksitas serta saling terkait antar bagian satunya dengan lainnya. Informasi integrasi sangat bermanfaat untuk manajer ketika berada pada kondisi yang mengharuskan untuk melakukan pengambilan keputusan yang juga akan berpengaruh untuk bagian subunit yang lain pada perusahaan. Dengan adanya informasi yang terintegrasi dapat menjadi hal yang dipertimbangkan manajer terkait unsur integritas dalam mengevaluasi kinerja.

Beberapa penelitian terdahulu Ayu \& Dahen (2014) dan Sulkiah (2016) dan membuktikan bahwa karakteristik ISAM integration memiliki pengaruh positif signifikan terhadap kinerja manajerial. Penelitian Fitriani (2013) membuktikan antara karakteristik ISAM dengan kinerja manajerial tidak memiliki pengaruh.

\section{Pengaruh Ketidakpastian Lingkungan terhadap Kinerja Manajerial}

Ketidakpastian lingkungan yakni kondisi pada saat seseorang mempunyai kendala dalam memperkirakan situasi sekitar sehingga sulit untuk mengetahui apakah keputusan yang telah diambil gagal atau berhasil. Ketidakpastian lingkungan yang dialami oleh perusahaan alami menjadi salah satu faktor yang dapat berpengaruh kepada manajer dalam memperkirakan apa yang terjadi di masa depan. Pada keadaan ketidakpastian lingkungan tinggi, manajer akan dihadapi oleh situasi dimana sulitnya untuk memahami lingkungan yang sangat kompleks, sehingga manajer akan lebih sulit untuk membuat perencanaan serta pengendalian kepada perusahaan (Duncan, 1972) dalam (Fitrianingrum \& Wijayanti, 2011).

Dari pemaparan di atas kesimpulannya adalah bahwa apabila manajer mengalami kesulitan untuk membuat perencanaan serta pengendalian apabila kondisi ketidakpastian lingkungan meningkat. Perencanaan dan pengendalian menjadi bermasalah jika tidak dapat terprediksinya kondisi yang terjadi di masa mendatang. Maka kinerja manajerial menjadi semakin rendah apabila semakin tinggi ketidakpastian lingkungan.

Lathifah (2012), Frestilia (2013), dan Sulkiah (2016) dalam hasil penelitiannya mengatakan bahwa antara adanya pengaruh signifikan negatif ketidakpastian lingkungan dan kinerja manajerial. Namun ada beberapa penelitian hasilnya mengatakan bahwa adanya pengaruh signifikan positif antara ketidakpastian lingkungan dan kinerja manajerial (Damayanti et al., 2015; Erna \& Dwi, 2006; Fitrianingrum \& Wijayanti, 2011)

\section{Pengaruh Desentralisasi terhadap Kinerja Manajerial}

Desentralisasi adalah delegasi tanggung jawab serta kekuasaan kepada manajer tingkat lebih rendah. Pada kondisi ini manajer tingkat lebih tinggi memberikan tanggung jawab untuk melakukan kebijakan secara independen kepada manajer bawahan. Sifat independen pada seorang manajer dapat berdampak semakin leluasanya manajer untuk berfikir dan bertindak untuk mencapai tujuan perusahaan. Dengan kondisi administratif yang semakin kompleks, maka desentralisasi sangat diperlukan dalam 
perusahaan. Struktur perusahaan mempunyai peranan penting karena berpengaruh terhadap kinerja bagian sub unit maupun kinerja perusahaan. Hal tersebut terjadi karena adanya desentralisasi, manajer yang berada pada subunit yang dipimpinnya untuk mengambil keputusan, sehingga kualitas keputusannya menjadi lebih baik.

Erna \& Dwi (2006), Wuryani \& Djati (2007), Damayanti et al (2015), dan Senduk et al (2017) telah melakukan penelitian sebelumnya dan mengatakan bahwa terdapat pengaruh signifikan dan positif antara desentralisasi dan kinerja manajerial. Pendelegasian wewenang sangat penting dilakukan oleh pihak manajer atasan kepada manajer bawahan agar para manajer tingkat bawah dapat merespon secara cepat juga tepat mengenai situasi-situasi ekonomi juga budaya di lingkungan sekitar. Dengan demikian desentralisasi dapat meningkatkan efektivitas kinerja manajerial.

\section{Metode Penelitian \\ Sampel dan Data}

Populasi penelitian adalah manajer puncak dan manajer menengah di 18 perusahaan BUMN di Banda Aceh yang berjumlah 85 orang. Kemudian rumus slovin didapatkan jumlah sampel sebanyak 70 manajer. Penarikan sampel penelitian ini dilakukan teknik simple random sampling.

Penelitian ini menggunakan sumber data primer. Adapun metode pengumpulan data penelitian ini adalah melalui kuesioner yang diantarkan secara langsung ke 18 kantor BUMN di Banda Aceh. Dimana butir-butir pertanyaan pada kuesioner sudah mewakilkan variabel yang ada pada penelitian ini.

\section{Pengukuran Variabel}

1. Kinerja Manajerial

Kinerja manajerial adalah hasil kerja dan pencapaian manajer dalam menjalankan fungsi manajemen. Fungsi manajemen tersebut berupa perencanaan, investigasi, koordinasi, evaluasi, supervisi, pengaturan staf, negosiasi, representasi, dan kinerja keseluruhan. Instrumen yang digunakan adalah Mahoney, Jerdee, \& Carrooll, (1965) terdiri dari 9 item pertanyaan.

\section{Broad scope}

Broad scope merupakan ruang lingkup informasi yang terkait dengan informasi ekonomi maupun non ekonomi bercakupan luas. Variabel ini diukur dengan 5 item pertanyaan dari Chenhall \& Morris (1986).

\section{Timeliness}

Timeliness adalah informasi yang disampaikan tepat waktu. Informasi dikatakan tepat waktu apabila mencerminkan kondisi yang terjadi saat ini sesuai dengan kebutuhan manajer (Bordner, 1995) dalam (Jayanti \& Widodo, 2010). Variabel timelineesi diukur dengan instrumen yang dikembangkan oleh Chenhall \& Morris (1986) terdiri dari 4 item pertanyaan.

\section{Aggregation}

Informasi agregasi dikirimkan secara singkat, tetapi tidak mengurangi nilai kualitas informasi, juga dapat membantu meningkatkan efisiensi manajemen, karena lebih sedikit waktu yang diperlukan. (Setyolaksono, 2011). Pengukuran variabel ini menggunakan 8 item pertanyaan menggunakan instrumen yang dikembangkan oleh Chenhall \& Morris (1986).

\section{Integration}

Integration dapat dijadikan alat koordinasi antar segmen sub unit yang satu dengan yang lainnya. Informasi integrasi semakin akan dibutuhkan jika semakin banyak segmen dalam bagian-bagian unit organisasi. Pengukuran variabel menggunakan instrumen yang dikembangkan oleh Chenhall \& Morris (1986) yang terdiri dari 3 pertanyaan.

6. Ketidakpastian Lingkungan

Ketidakpastian lingkungan suatu kondisi individu tidak mampu meramalkan secara tepat apa yang akan terjadi di lingkungan eksternal perusahaan. Pengukuran terdiri atas 11 item pertanyaan dengan menggunakan instrumen Duncan (1972).

7. Desentralisasi

Desentralisasi adalah praktik pendelegasian wewenang ketika membuat keputusan ke tingkat yang lebih rendah. Instrumen pada variabel ini menggunakan instrumen yang dikembangkan oleh 
Gordon \& Narayanan (1984) yang terdiri atas 5 item pertanyaan.

\section{Metode Analisis dan Rancangan Pengujian Hipotesis}

\section{Uji Validitas dan Reliabilitas}

Pemeriksaan validasi dilakukan untuk menentukan apakah kuesioner yang valid digunakan untuk mengumpulkan data dalam penelitian ini.Kuesioner dianggap valid jika pertanyaan yang ada dapat dijawab atau menunjukkan apa yang diukur dengan kuesioner (Ghozali, 2016).

Uji reliabilitas untuk menguji kehandalan kuesioner (Sekaran \& Bougie, 2017: 29). Perhitungan reliabilitas dilakukan untuk setiap butir pertanyaan kuesioner (Sanusi, 2011:81).

\section{Uji Asumsi Klasik}

\section{1) Uji Normalitas}

Tujuan dari uji normalitas adalah untuk melihat apakah model regresi adalah variabel dependen dengan variabel independen dengan distribusi normal atau sebaliknya. Dikatakan bahwa model regresi baik jika didistribusikan secara normal (Ghozali, 2016).

\section{2) Uji Multikolinearitas}

Tes multikolinieritas dilakukan untuk memeriksa apakah penilaian ada di antara variabel independen. Model regresi yang baik adalah bahwa tidak ada interaksi antara variabel independen, dan jika ada perbedaan antara variabel independen, masalah multiko muncul. Nilai yang biasanya digunakan untuk menonton adalah toleransi multiko $<10$ atau vif $>10$ (Ghozali, 2016).

3) Uji Heterokedastisitas

Bertujuan untuk melihat model regresi, apakah ada kesamaan dalam varians dari residual antara pengamatan yang dilakukan. Model regresi yang baik adalah model regresi yang tidak mengalami heteroskedastisitas (Ghozali, 2016).

\section{Uji Hipotesis}

Penelitian ini mengunakan metode analisis regresi berganda. Persamaan regresi linear berganda (Ghozali, 2016), adalah sebagai berikut:

$$
\begin{aligned}
& \mathrm{Y}=\mathrm{a}+\mathrm{b} 1 \mathrm{X} 1+\mathrm{b} 2 \mathrm{X} 2+\mathrm{b} 3 \mathrm{X} 3+\mathrm{b} 4 \mathrm{X} 4+\mathrm{b} 5 \mathrm{X} 5+\mathrm{b} 6 \mathrm{X} 6 \\
& +\mathrm{e} \\
& \text { Keterangan: } \\
& \mathrm{Y} \quad \text { = Kinerja Manajerial } \\
& \mathrm{a} \quad=\text { Konstanta } \\
& \mathrm{b} \quad=\text { Koefisien regresi } \\
& \mathrm{X} 1 \quad \text { = Broad scope } \\
& \mathrm{X} 2 \quad=\text { Timeliness } \\
& \mathrm{X} 3 \quad \text { = Aggregation } \\
& \mathrm{X} 4 \quad \text { = Integration } \\
& \mathrm{X} 5 \quad \text { = Ketidakpastian lingkungan } \\
& \mathrm{X} 6 \quad \text { = Desentralisasi } \\
& \mathrm{e} \quad \text { = Error }
\end{aligned}
$$

\section{Pengujian Hipotesis secara Parsial (Uji t)}

Uji-t menunjukkan efek dari satu variabel independen sebagian ketika menjelaskan variabel dependen. Uji dengan membandingkan hasil $\mathrm{t}_{\text {hitung }}$ dengan $t_{\text {tabel. }}$.

\section{Pengujian Hipotesis secara Simultan (Uji F)}

Uji $F$ adalah metode analisis data yang memungkinkan untuk menentukan tingkat pengaruh antara variabel secara keseluruhan atau pada saat yang sama, dan juga untuk menguji kepatuhan dengan model yang digunakan.

\section{Koefisien Determinasi $\left(\mathbf{R}^{2}\right)$}

Koefisien determinasi cenderung melihat bagaimana model regresi dapat menjelaskan variabel dependen. Faktor definisi berkisar dari 0 hingga 1. Jika nilai definisi mendekati 0 , variabel independen tidak banyak berpengaruh pada variabel dependen. Jika nilai definisi mendekati 1, maka variabel independen memiliki pengaruh besar pada variabel dependen (Ghozali, 2016).

\section{Hasil Dan Pembahasan Deskripsi Data}

Jumlah responden yaitu 70 responden yang terbagi menjadi 18 manajer puncak serta 52 manajer menengah. Setelah kuesioner diisi oleh responden, kemudian jawaban dari setiap responden ditabulasikan dengan software Microsoft Excel dan SPSS.

Peneliti mengantarkan secara langsung kuesioner, kemudian terdapat beberapa yang langsung diisi dan dikembalikan di hari yang sama, dan adapula yang meminta kuesioneruntuk ditinggalkan kemudian 
dijemput kembali pada waktu yang telah disepakati. Dari 70 kuesioner yang dibagikan kepada responden semuanya dapat dikembalikan kepada peneliti, artinya

\section{Karakteristik Responden Penelitian} pengembalian kuesioner pada penelitian ini sebesar $100 \%$.

Tabel 4.1

Karakteristik Responden Penelitian

\begin{tabular}{|c|l|c|c|}
\hline No. & \multicolumn{1}{|c|}{ Karakteristik Responden } & Jumlah & Frekuensi \\
\hline 1. & Jenis Kelamin & 52 & $74,3 \%$ \\
\hline & 1.1 Pria & 18 & $25,7 \%$ \\
\hline & 1.2 Wanita & 70 & $100 \%$ \\
\hline & Total & & $32,9 \%$ \\
\hline 2. & Usia & 23 & $41,4 \%$ \\
\hline & $2.125-35$ tahun & 29 & $15,7 \%$ \\
\hline & $2.235-45$ tahun & 11 & $10 \%$ \\
\hline & $2.345-50$ tahun & 7 & $100 \%$ \\
\hline & $2.4>50$ tahun & 70 & $18,6 \%$ \\
\hline & Total & & $60 \%$ \\
\hline 3. & Pendidikan & 13 & $11,4 \%$ \\
\hline & 3.1 D3 & 42 & $10 \%$ \\
\hline & 3.2 S1 & 8 & $100 \%$ \\
\hline & 3.3 S2 & 7 & \\
\hline & 3.4 Lain-lain & 70 & $74,3 \%$ \\
\hline & Total & & $25,7 \%$ \\
\hline 4. & Jabatan & 18 & $100 \%$ \\
\hline & 4.1 Manajer Puncak & 52 & \\
\hline & 4.2 Manajer Menengah & 70 & \\
\hline & Total & & \\
\hline
\end{tabular}

Sumber: Data Diolah (2019)

\section{Hasil Pengujian Validitas dan Reliabilitas Hasil Uji Validitas}

Pengujian kualitas data pada penelitian ini diuji secara statistik menggunakan uji koefisien korelasi

Tabel 4.1

Hasil Uji Validitas

\begin{tabular}{|c|c|c|c|c|c|}
\hline No & Item & Variabel & Koefisien Korelasi ( $\left.\mathbf{R}_{\text {Hitung }}\right)$ & Nilai Kritis $5 \%\left(\mathbf{R}_{\text {Tabel }}\right)$ & Ket \\
\hline 1 & $\mathrm{X} 1.1$ & \multirow{5}{*}{ Broad scope $\left(\mathrm{X}_{1}\right)$} & 0,778 & \multirow{5}{*}{0,235} & \multirow{5}{*}{ Valid } \\
\hline 2 & $\mathrm{X} 1.2$ & & 0,787 & & \\
\hline 3 & $\mathrm{X} 1.3$ & & 0,757 & & \\
\hline 4 & $\mathrm{X} 1.4$ & & 0,704 & & \\
\hline 5 & $\mathrm{X} 1.5$ & & 0,702 & & \\
\hline 6 & $\mathrm{X} 2.1$ & \multirow{2}{*}{ Timeliness $\left(\mathrm{X}_{2}\right)$} & 0,823 & \multirow{2}{*}{0,235} & \multirow{2}{*}{ Valid } \\
\hline 7 & $\mathrm{X} 2.2$ & & 0,880 & & \\
\hline
\end{tabular}




\begin{tabular}{|c|c|c|c|c|c|}
\hline No & Item & Variabel & Koefisien Korelasi ( $\left.\mathbf{R}_{\text {Hitung }}\right)$ & Nilai Kritis $5 \%\left(\mathbf{R}_{\text {Tabel }}\right)$ & Ket \\
\hline 8 & $\mathrm{X} 2.3$ & & 0,848 & & \\
\hline 9 & $\mathrm{X} 2.4$ & & 0,815 & & \\
\hline 10 & $\mathrm{X} 3.1$ & \multirow{8}{*}{ Aggregation $\left(\mathrm{X}_{3}\right)$} & 0,730 & \multirow{8}{*}{0,235} & \multirow{8}{*}{ Valid } \\
\hline 11 & $\mathrm{X} 3.2$ & & 0,782 & & \\
\hline 12 & $\mathrm{X} 3.3$ & & 0,672 & & \\
\hline 13 & $\mathrm{X} 3.4$ & & 0,713 & & \\
\hline 14 & $\mathrm{X} 3.5$ & & 0,635 & & \\
\hline 15 & $\mathrm{X} 3.6$ & & 0,866 & & \\
\hline 16 & $\mathrm{X} 3.7$ & & 0,775 & & \\
\hline 17 & $\mathrm{X} 3.8$ & & 0,589 & & \\
\hline 18 & $\mathrm{X} 4.1$ & \multirow{3}{*}{ Integration $\left(\mathrm{X}_{4}\right)$} & 0,881 & \multirow{3}{*}{0,235} & \multirow{3}{*}{ Valid } \\
\hline 19 & $\mathrm{X} 4.2$ & & 0,896 & & \\
\hline 20 & $\mathrm{X} 4.3$ & & 0,899 & & \\
\hline 21 & $\mathrm{X} 5.1$ & \multirow{11}{*}{ Ketidakpastian Lingkungan (X5) } & 0,788 & \multirow{11}{*}{0,235} & \multirow{11}{*}{ Valid } \\
\hline 22 & $\mathrm{X} 5.2$ & & 0,634 & & \\
\hline 23 & $\mathrm{X} 5.3$ & & 0,795 & & \\
\hline 24 & $\mathrm{X} 5.4$ & & 0,680 & & \\
\hline 25 & $\mathrm{X} 5.5$ & & 0,794 & & \\
\hline 26 & $\mathrm{X} 5.6$ & & 0,713 & & \\
\hline 27 & $\mathrm{X} 5.7$ & & 0,697 & & \\
\hline 28 & $\mathrm{X} 5.8$ & & 0,724 & & \\
\hline 29 & X5.9 & & 0,707 & & \\
\hline 30 & $\mathrm{X} 5.10$ & & 0,793 & & \\
\hline 31 & $\mathrm{X} 5.11$ & & 0,794 & & \\
\hline 32 & X6.1 & \multirow{5}{*}{ Desetralisasi (X6) } & 0,733 & \multirow{5}{*}{0,235} & \multirow{5}{*}{ Valid } \\
\hline 33 & $\mathrm{X} 6.2$ & & 0,827 & & \\
\hline 34 & X6.3 & & 0,760 & & \\
\hline 35 & X6.4 & & 0,762 & & \\
\hline 36 & $\mathrm{X} 6.5$ & & 0,689 & & \\
\hline 37 & Y1 & \multirow{9}{*}{ Kinerja Manajerial (Y) } & 0,864 & \multirow{9}{*}{0,235} & \multirow{9}{*}{ Valid } \\
\hline 38 & $\mathrm{Y} 2$ & & 0,695 & & \\
\hline 39 & Y3 & & 0,686 & & \\
\hline 40 & Y4 & & 0,861 & & \\
\hline 41 & Y5 & & 0,713 & & \\
\hline 42 & Y6 & & 0,822 & & \\
\hline 43 & $\mathrm{Y7}$ & & 0,780 & & \\
\hline 44 & Y8 & & 0,824 & & \\
\hline 45 & Y9 & & 0,861 & & \\
\hline
\end{tabular}

Sumber: Data diolah (2019)

Berdasarkan Tabel 4.2, maka disimpulkan setiap butir pertanyaan pada kuesioner penelitian ini dikatakan valid. Hal ini dapat dibuktikan dengan melihat nilai korelasi lebih besar daripada nilai kritis $(\mathrm{N}=70)$ yang menunjukkan angka 0,235 atau memiliki nilai signifikan butir pertanyaan secara keseluruhan 
sebesar 5\%. Jadi, keseluruhan perolehan data dinyatakan valid serta layak digunakan untuk penelitian ini.

\section{Hasil Uji Reliabilitas}

Uji dapat dilakukan hanya pada kuesioner yang memiliki validitas dengan tujuan mengetahui kehandalan dari kuesioner yang digunakan. Uji reliabilitas dilakukan atas 45 butir pertanyaan diuji dengan statistik menggunakan cronchbach's coefficient alpha lebih besar dari 0,60 melalui bantuan SPSS.

Tabel 4.3

Hasil Uji Reliabilitas

\begin{tabular}{|l|c|c|c|c|}
\hline \multicolumn{1}{|c|}{ Variabel } & $\begin{array}{c}\text { Jumlah Item } \\
\text { Pernyataan }\end{array}$ & Cronbach Alpha & $\begin{array}{c}\text { Nilai Kritis Cronbach's } \\
\text { Alpha }\end{array}$ & Ket \\
\hline Broad scope (X1) & 5 & 0,796 & 0,60 & Reliabel \\
\hline Timeliness (X2) & 4 & 0,863 & 0,60 & Reliabel \\
\hline Aggregation (X3) & 8 & 0,870 & 0,60 & Reliabel \\
\hline Integration (X4) & 3 & 0,869 & 0,60 & Reliabel \\
\hline $\begin{array}{l}\text { Ketidakpastian } \\
\text { Lingkungan (X5) }\end{array}$ & 11 & 0,915 & 0,60 & Reliabel \\
\hline Desentralisasi (X6) & 5 & 0,809 & 0,60 & Reliabel \\
\hline Kinerja Manajerial (Y) & 9 & 0,923 & 0,60 & \\
\hline
\end{tabular}

Sumber : Data diolah (2019)

Berdasarkan Tabel 4.3, disimpulkan kuesioner pada penelitian ini dapat mencapai tujuan penelitian, hal ini diketahui nilai koefisien cronbach alpha >0,60.

\section{Pengujian Asumsi Klasik \\ Hasil Uji Normalitas}

Tabel 4.4

Uji Normalitas Kolmogrov-Smirnov Test

\begin{tabular}{|c|c|}
\hline & $\begin{array}{c}\text { Unstandardized } \\
\text { Residual }\end{array}$ \\
\hline $\begin{array}{c}\text { Asymp. Sig. (2- } \\
\text { tailed) }\end{array}$ & 0,163 \\
\hline
\end{tabular}

Sumber: Data diolah (2019)
Gambar 4.1

Uji Normalitas

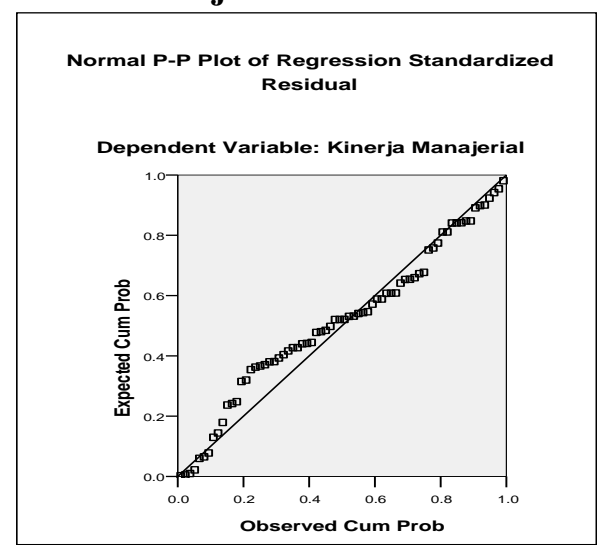

Sumber : Data diolah (2019)

Dari Tabel 4.4, diketahui nilai signifikansi sebesar 0,163. Nilai signifikansi > 0,05, jadi data dikatakan berdistribusi secara normal. Kemudian pada gambar 4.1 grafik normal probability plot menunjukkan penyebaran data (titik) mengikuti garis diagonalnya. Maka residual data terdistribusi normal dengan asumsi normalitas terpenuhi. 


\section{Hasil Uji Multikolinearitas}

Tabel 4.5

Hasul Uji Multikolinearitas

\begin{tabular}{|l|c|c|}
\hline \multicolumn{1}{|c|}{ Model } & Tolerance & $\mathrm{VIF}$ \\
\hline Broad scope & 0,423 & 2,364 \\
Timeliness & 0,369 & 2,712 \\
Aggregation & 0,315 & 3,178 \\
Integration & 0,438 & 2,284 \\
Ketidakpastian Lingkungan & 0,714 & 1,400 \\
Desentralisasi & 0,757 & 1,321 \\
\hline
\end{tabular}

Sumber : Data diolah (2019)

Dari Tabel 4.5, disimpulkan bahwa tidak terjadinya multikolinearitas. Hal ini dapat dibuktikan dengan masing-masing model memiliki nilai tolerance yang $>0,10$ serta VIF $<10$.

\section{Hasil Uji Heterokedastisitas}

Tabel 4.6

Hasil Uji Heterokedastisitas

\begin{tabular}{|l|c|}
\hline \multicolumn{1}{|c|}{ Model } & Sig. \\
\hline Broad scope & 0,290 \\
Timeliness & 0,435 \\
Aggregation & 0,295 \\
Integration & 0,704 \\
Ketidakpastian Lingkungan & 0,598 \\
Desentralisasi & 0,517 \\
\hline
\end{tabular}

Sumber : Data diolah (2019)

Dari Tabel 4.5, disimpulkan bahwa tidak terjadinya multikolinearitas. Hal ini dapat dibuktikan dengan masing-masing model memiliki nilai tolerance yang $>0,10$ serta VIF $<10$.

\section{Gambar 4.2}

Uji Heterokedastisitas

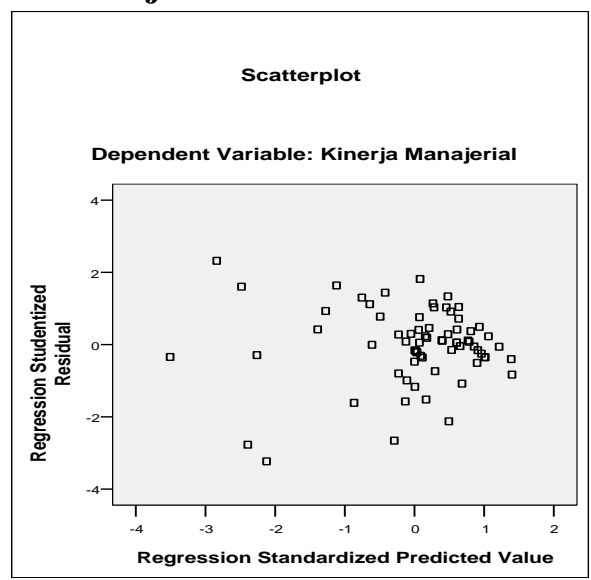

Sumber : Data diolah (2019)

Berdasarkan Gambar 4.2 dapat dilihat bahwa tidak terdapat pola tertentu atau titik-titik menyebar di atas dan di bawah angka 0 pada sumbu Y, maka model regresi pada penelitian ini tidak terjadi heterokedastisitas.

\section{Hasil Metode Analisis Regresi Linear Berganda}

Metode yang digunakan untuk mengetahui pengaruh variabel bebas terhadap variabel terikat adalah analisis regresi linear berganda yang dibantu dengan perangkat SPSS versi 20. Terdapat enam variabel bebas dalam penelitian ini yaitu broad scope $\left(\mathrm{X}_{1}\right)$, timeliness $\left(\mathrm{X}_{2}\right)$, aggregation $\left(\mathrm{X}_{3}\right)$, Integration $\left(\mathrm{X}_{4}\right)$, ketidakpastian lingkungan $\left(\mathrm{X}_{5}\right)$, dan desentralisasi $\left(\mathrm{X}_{6}\right)$. Sedangkan untuk variabel terikatnya adalah kinerja manajerial (Y).

Tabel 4.7

Hasil Regresi Linear Berganda

\begin{tabular}{|c|c|c|c|c|c|c|c|}
\hline \multicolumn{8}{|c|}{$\mathrm{Y}=0,254+0,207 \mathrm{X} 1+0,227 \mathrm{X} 2+0,337 \mathrm{X} 3+0,211 \mathrm{X} 4-0,176 \mathrm{X} 5+0,147 \mathrm{X} 6+\mathrm{e}$} \\
\hline Uraian & Constant & X1 & $\mathbf{X 2}$ & $\mathbf{X 3}$ & X4 & X5 & X6 \\
\hline t. Value & 0,569 & 2,296 & 2,347 & 2,640 & 2,478 & $-2,120$ & 2,146 \\
\hline Sig. Value & $\mathbf{0 , 5 7 2}$ & $\mathbf{0 , 0 2 5}$ & $\mathbf{0 , 0 2 2}$ & $\mathbf{0 , 0 1 0}$ & $\mathbf{0 , 0 1 6}$ & $\mathbf{0 , 0 3 8}$ & $\mathbf{0 , 0 3 6}$ \\
\hline F value / Sig. F & \multicolumn{7}{|c|}{$38,136 / 0,000$} \\
\hline $\mathbf{R} / \mathbf{R}^{2} / \mathrm{Adj} . \mathbf{R}^{2}$ & \multicolumn{7}{|c|}{$0,886 / 0,784 / 0,764$} \\
\hline
\end{tabular}

Sumber : Data diolah (2019) 
Pengaruh broad scope, timeliness, aggregation, integration, ketidakpastian lingkungan, dan desentralisasi terhadap kinerja manajerial

Pada tabel 4.7 hasil pengujian broad scope, timeliness, aggregation, integration, ketidakpastian lingkungan, serta desentralisasi, menunjukkan nilai $F_{\text {hitung }}$ sebesar 38,136. Dengan taraf signifikansi sebesar 0,05 dan tingkat keyakinan 95\%, maka diperoleh nilai df $1=6$ dan df2 $=63$ maka nilai $F_{\text {tabel }}$ sebesar 2,25. $F_{\text {hitung }}>F_{\text {tabel }}$ yaitu 38,136>2,25 dan nilai sig 0,000 , artinya lebih kecil daripada taraf signifikansi, maka broad scope, timeliness, aggregation, integration, ketidakpastian lingkungan, serta desentralisasi berpengaruh secara simultan terhadap kinerja manajerial pada BUMN di Banda Aceh.

\section{Pengaruh Broad scope terhadap Kinerja Manajerial}

Nilai broad scope (X1) sebesar 0,207 dan positif, artinya broad scope memberikan kontribusi positif dalam mempengaruhi kinerja manajerial yaitu sebesar 20,7\%. Apabila broad scope meningkat sejumlah $1 \%$, akan meningkatkan kinerja manajerial sejumlah 20,7\% dengan menggunakan asumsi untuk variabel bebas lain sama dengan nol atau konstan. Dan dapat diketahui pada tabel 4.7 bahwa nilai $t_{\text {hitung }}>t_{\text {tabel }}$ yaitu 2,296 >1,99, serta nilai signifikansi (sig.) broad scope sebesar 0,025 dibandingkan dengan 0,05maka terdapat pengaruh positif serta signifikan antara broad scope dengan kinerja manajerial.

Hasil ini berbanding lurus dengan perumusan hipotesis yang telah dipaparkan. Hasil penelitian ini sejalan atau konsisten dengan hasil penelitian sebelumnya, yaitu penelitian Fitriani (2013), Ayu \& Dahen (2014), dan Sulkiah (2016) yang manyimpulkan bahwa antara penggunaan karakteristik ISAM broad scope dan kinerja manajerial memiliki pengaruh signifikan positif.

Dalam menjalankan tugasnya infrmasi broad scope sangat dibutuhkan oleh manajer karena dapat menyediakan informasi bercakupan luas juga lengkap yang meliputi aspek ekonomi dan non ekonomi. Dengan adanya informasi yang lengkap mengenai kondisi internal maupun eksternal perusahaan mengenai aspek ekonomi dan non ekonomi, maka perolehan hasil sejalan dengan yang direncanakan dan kinerja manajerial menjadi menigkat.

\section{Pengaruh Timeliness terhadap Kinerja Manajerial}

Nilai timeliness (X2) sebesar 0,227 dan positif, artinya timeliness memberikan kontribusi positif dalam mempengaruhi kinerja manajerial yaitu sebesar $22,7 \%$. Apabila timeliness meningkat sejumlah $1 \%$, akan meningkatkan kinerja manajerial sejumlah 22,7\% dengan menggunakan asumsi untuk variabel lain sama dengan nol atau konstan. Dan dapat diketahui pada tabel 4.7 bahwa nilai $t_{\text {hitung }}>t_{\text {tabel }}$ yaitu 2,347 $>1,99$, serta nilai signifikansi (sig.) timeliness sebesar 0,022 dibandingkan dengan 0,05 , maka terdapat pengaruh positif serta signifikan antara timeliness dengan kinerja manajerial.

Hasil ini berbanding lurus dengan perumusan hipotesis yang telah dipaparkan. Hasil penelitian ini sejalan atau konsisten dengan hasil penelitian sebelumnya, yaitu penelitian Fitriani (2013), Ayu \& Dahen (2014), dan Sulkiah (2016) yang menyimpulkan bahwa antara penggunaan karakteristik ISAM timeliness dan kinerja manajerial memiliki pengaruh signifikan positif.

Pengambilan keputusan akan menjadi tepat waktu dengan adanya informasi yang disampaikan dengan cepat, tepat, serta akurat.Karakteristik ISAM timeliness dapat memberikan respon yang cepat terhadap keputusan yang diambil, sehingga dengan begitu kinerja manajerial akan meningkat. pengambilan keputusan yang tepat dan cepat akan menghasilkan kinerja manajerial yang baik.

\section{Pengaruh Aggregation terhadap Kinerja Manajerial \\ Nilai aggregation (X3) sebesar 0,337 dan} positif, artinya aggregation memberikan kontribusi positif dalam mempengaruhi kinerja manajerial yaitu sebesar $33,7 \%$. Apabila aggregation meningkat sejumlah $1 \%$, akan meningkatkan kinerja manajerial sejumlah $33,7 \%$ dengan menggunakan asumsi untuk variabel lain sama dengan nol atau konstan. Dan dapat diketahui pada tabel 4.7 bahwa nilai $t_{\text {hitung }}>t_{\text {tabel }}$ yaitu $2,640>1,99$, serta nilai signifikansi (sig.) aggregation sebesar 0,010 dibandingkan dengan 0,05, maka terdapat pengaruh positif serta signifikan antara aggregation dengan kinerja manajerial. 
Hasil ini berbanding lurus dengan perumusan hipotesis yang telah dipaparkan. Hasil penelitian ini sejalan atau konsisten dengan hasil penelitian sebelumnya, yaitu penelitian Ayu \& Dahen (2014) dan Sulkiah (2016) yang menyimpulkan bahwa antara penggunaan karakteristik ISAM aggregation dan kinerja manajerial memiliki pengaruh signifikan positif.

Informasi aggregation dapat menyajikan informasi secara ringkas tetapi masih mengandung hal penting jadi dapat menghemat waktu manajer untuk menjadi bahan pertimbangan dalam pengambilan keputusan. Informasi yang teragregasi dapat meningkatkan efisiensi dan juga efektivitas kinerja manajerial.

\section{Pengaruh Integration terhadap Kinerja Manajerial}

Nilai integration (X4) sebesar 0,211 dan positif, artinya integration memberikan kontribusi positif dalam mempengaruhi kinerja manajerial yaitu sebesar $21,1 \%$. Apabila integration meningkat sejumlah $1 \%$, akan meningkatkan kinerja manajerial sejumlah $21,1 \%$ dengan menggunakan asumsi untuk variabel lain sama dengan nol atau konstan. Dan dapat diketahui pada tabel 4.7 bahwa nilai $\mathrm{t}_{\text {hitung }}>\mathrm{t}_{\text {tabel }}$ yaitu $2,478>1,99$, serta nilai signifikansi (sig.) integration sebesar 0,016 dibandingkan dengan 0,05 , maka terdapat pengaruh positif serta signifikan antara integration dengan kinerja manajerial.

Hal ini berbanding lurus dengan hipotesis yang sudah dirumuskan. Hasil penelitian ini sejalan atau konsisten dengan hasil penelitian sebelumnya, yaitu penelitian Ayu \& Dahen (2014), dan Sulkiah (2016) yang menyimpulkan bahwa antara penggunaan karakteristik ISAM integration dan kinerja manajerial memiliki pengaruh signifikan positif.

Diperlukan informasi terintegrasi ketika manajer harus mengambil keputusan yang akan berdampak pada bagianatau unit yang lainnya yang nantinya akan meningkatkan kinerja manajerial.

\section{Pengaruh Ketidakpastian Lingkungan terhadap Kinerja Manajerial}

Nilai ketidakpastian lingkungan (X5) sebesar 0,176 dan negatif, artinya ketidakpastian lingkungan memberikan kontribusi negatif dalam mempengaruhi kinerja manajerial sebesar 17,6\%. Apabila ketidakpastian lingkungan sejumlah $1 \%$, akan meningkatkan kinerja manajerial sejumlah $17,6 \%$ dengan menggunakan asumsi untuk variabel lain sama dengan nol atau konstan. Dan dapat diketahui pada tabel 4.7 bahwa nilai $t_{\text {hitung }}>t_{\text {tabel }}$ yaitu 2,120 $>1,99$, serta nilai signifikansi (sig.) ketidakpastian lingkungan sebesar 0,016 dibandingkan dengan 0,05, maka terdapat pengaruh negatif serta signifikan antara ketidakpastian lingkungan dengan kinerja manajerial.

Hasil ini berbanding lurus dengan perumusan hipotesis yang telah dipaparkan. Hasil penelitian ini sejalan atau konsisten dengan hasil penelitian sebelumnya, yaitu penelitian Frestilia (2013) yang menyimpulkan bahwa ketidakpastian lingkungan berpengaruh signifikan negatif terhadap kinerja manajerial.

Ketidakpastian lingkungan yang meningkat akan membuat seorang manajer kesulitan ketika membuat perencanaan dan juga pengendalian. Perencanaan dan penendalian akan bermasalah jika tidak dapat terprediksinya situasi yang akan terjadi di masa depan. Maka semakin tinggi ketidakpastian lingkungan maka kinerja manajerial akan semakin rendah pula.

\section{Pengaruh Desentralisasi terhadap Kinerja Manajerial}

Nilai desentralisasi (X6) sebesar 0,147 dan positif, artinya desentralisasi memberikan kontribusi positif dalam mempengaruhi kinerja manajerial sebesar $14,7 \%$. Apabila desentralisasi sejumlah $1 \%$, akan meningkatkan kinerja manajerial sejumlah 14,7\% dengan menggunakan asumsi untuk variabel lain sama dengan nol atau konstan. Dan dapat diketahui pada tabel 4.7 bahwa nilai $t_{\text {hitung }}>t_{\text {tabel }}$ yaitu 2,146 $>1,99$, serta nilai signifikansi (sig.) desentralisasi sebesar 0,036 dibandingkan dengan 0,05 , maka terdapat pengaruh positif serta signifikan antara desentralisasi dengan kinerja manajerial.

Hasil ini berbanding lurus dengan perumusan hipotesis yang telah dipaparkan. Hasil penelitian ini sejalan atau konsisten dengan hasil penelitian sebelumnya yang juga dijadikan referensi dalam penelitian ini, yaitu Damayanti et al. (2015) dan Senduk et al. (2017) yang membuktikan bahwa adanya pengaruh positif serta signifikan antara desentralisasi dengan kinerja manajerial.

Dengan adanya desentralisasi atau pendelegasian wewenang menyebabkan meningkatnya 
kualitas keputusan yang diambil oleh manajer, karena manajer yang bertugas pada unit tersebut lebih memahami secara akurat apa yang terjadi pada unitnya sendiri dibandingkan dengan manajer umum. Desentralisasi dapat membuat kinerja manajerial meningkat akibat dari meningkatnya motivasi manajer dengan terpenuhinya kebutuhan actual diri yaitu merasa diterima, merasadibutuhkan, dan merasa diikutsertakan (Damayanti et al., 2015).

\section{Kesimpulan, Keterbatasan dan Saran Kesimpulan}

Berdasarkan paparan hasil analisis serta pembahasan sebelumnya, maka kesimpulan pada penelitian ini adalah :

1) Broad scope berpengaruh signifikan positif terhadap kinerja manajerial.

2) Timeliness berpengaruh signifikan positif terhadap kinerja manajerial.

3) Aggregation berpengaruh signifikan positif terhadap kinerja manajerial.

4) Integration berpengaruh signifikan positif terhadap kinerja manajerial.

5) Ketidakpastian lingkungan berpengaruh signifikan negatif terhadap kinerja manajerial.

6) Desentralisasi berpengaruh signifikan positif terhadap kinerja manajerial.

7) Broad scope, timeliness, aggregation, integration, ketidakpastian lingkungan, dan desentralisasi secara simultan berpengaruh terhadap kinerja manajerial.

\section{Keterbatasan}

Peneliti memiliki keterbatasan dalam penelitian ini, yaitu menggunakan metode penyebaran kuesioner dalam mengumpulkan data, sehingga memungkinkan terdapatnya perbedaan antara persepsi dengan kondisi yang sebenarnya terjadi.

\section{Saran}

Para manajer di perusahaan BUMN diharapkan terus dapat meningkatkan kesadaran dan juga pemahaman akan pentingnya ISAM yang bersifat broad scope, timeliness, aggregation, dan integration dalam menjalankan kegiatan manajerial sehingga bermanfaat untuk dijadikan salah satu hal yang dapat dipertimbangkan dalam pengambilan keputusan manajerial. Para manajer diharapkan terus meningkatkan kesadaran dan juga pemahaman terhadap dampak yang ditimbulkan oleh ketidakpastian lingkungan pada masa mendatang, sehingga apa yang terlebih dahulu sudah direncanakan dapat dijalankan dengan tepat. Para manajer juga terus meningkatkan pemahaman akan kesadaran pentingnya melakukan pendelegasian wewenang dalam rangka meningkatkan kinerja mereka. Untuk penelitian selanjutnya adanya penambahan variabel moderasi ataupun intervening yang dapat mempengaruhi kinerja manajerial. Penelitian selanjutnya diharapkan adanya penambahan teknik pengumpulan data dengan wawancara secara langsung kepada para responden apabila memungkinkan.

\section{Daftar Pustaka}

Anwar Sanusi, 2011, Metode Penelitian Bisnis, Salemba Empat, Jakarta

Ayu, G., \& Dahenfitriaruh Karakteristik Informasi Sistem Akuntansi Manajemen terhadap Kinerja Manajerial Studi Empiris pada PT Bank Perkreditan Rakyat di Kabupaten Tanah Datar. Journal of Economic and Economic Education, $3(1)$, https://doi.org/https://doi.org/https://doi.org/10.2 2202/economica.2014.v3.i1.250

Azzumar, Syam, F., \& Zuraida. (2018). Influence of Characteristics of Management Accounting Information Systems to Managerial Performance with Variables of Business Strategy Modernations and Uncertainty Duties in Banking Companies in Aceh Province. International Journal of Academic Research in Business and Social Sciences, 8(7), 238-256. https://doi.org/10.6007/IJARBSS/v8-i7/4339

Chenhall, R. H., \& Morris, D. (1986). The impact of structure, environment, and interdependence on the perceived usefulness of management accounting systems. The Accounting Review, January(1),

$16-35$. https://doi.org/10.2307/247520

Damayanti, P. E., Sujana, E., \& Werastuti, D. N. S. (2015). Pengaruh Karakteristik Informasi Sistem Akuntansi Manajemen (SAM), Desentralisasi, dan Ketidakpastian Lingkungan terhadap Kinerja Manajerial (Studi Empiris pada Hotel Se-Kabupaten Buleleng). E-Journal S1 AK UPG, 3(1). 
Duncan, R. B. (1972). Characteristics of Organizational Environments and Perceived Environmental Uncertainty. Administrative Science Quarterly, 17(3), 313. https://doi.org/10.2307/2392145

Erna, \& Dwi, T. (2006). Pengaruh Desentralisasi, Karakteristik Informasi Sistem Akuntansi Manajemen dan Ketidakpastian Lingkungan terhadap Kinerja Manajerial pada PT. Alim Surya Steel. Jurnal Ilmu-Ilmu Ekonomi, 6(2), 109-116.

Fajari, G. (2015). Privatisasi Badan Usaha Milik Negara (BUMN) dalam Hal Memperluas Pemilikan Saham oleh Masyarakat sebagai Upaya Meningkatkan Kesejahteraan Umum (Tinjauan Atas UU No. 19 Tahun 2003 Tentang BUMN). Jurnal Nasional, 1(19), 6. https://doi.org/10.1017/CBO9781107415324.00 4

Fitriani. (2013). Pengaruh Penggunaan Karakteristik Informasi Akuntansi Manajemen terhadap Kinerja Manajerial. Jurnal Akuntansi FE Universitas Negeri Padang, 1(No. 3).

Fitrianingrum, D., \& Wijayanti, P. (2011). Ketidakpastian Lingkungan, Desentralisasi, terhadap Hubungan Karakteristik Informasi Sistem Akuntansi Manajemen dan Kinerja Manajerial (Studi Empiris Perusahaan Manufaktur di Kabupaten Semarang). Ekobis, 12(2),

$177-191$. https://doi.org/http://dx.doi.org/10.30659/ekobis .12.2.171-191

Frestilia, N. (2013). Pengaruh Pemanfaatan Teknologi Informasi, Karakteristik Informasi Sistem Akuntansi Manajemen dan Ketidakpastian Lingkungan terhadap Kinerja Manajerial. Jurnal Akuntansi FE Universitas Negeri Padang, 1(1).

Gordon, L. A., \& Narayanan, V. K. (1984). Management accounting systems, perceived environmental uncertainty and organization structure: An empirical investigation. Accounting, Organizations and Society, 9(1), $33-47$.

Hansen, D. R., \& Mowen, M. M. (1999). Akuntansi Manajermen.

Indriani, M., \& Nadir, N. (2015). Interaction Effect Of Budgetary Participation And Management Accounting System On Managerial
Performance: Evidence From Indonesia. Global Journal Of Business Research, 9(1), 1-13.

Jayanti, R. D., \& Widodo, H. (2010). Pengaruh Ketidakpastian Lingkungan dan Karakteristik Informasi Akuntansi Manajemen terhadap Kinerja Manajerial (Studi Pada Perusahaan Bumn di Jawa Timur). Bisnis Dan Manajemen, 2(2). https://doi.org/10.26740/bisma.v2n2.p150158

Lathifah, I. (2012). Peran Karakteristik Sistem Akuntansi Manajemen sebagai Mediator Hubungan Antara Ketidakpastian Lingkungan dengan Kinerja Manajerial. Jurnal Reviu Akuntansi Dan Keuangan, 2(2), 313-322.

Mahoney, T. A., Jerdee, T. H., \& Carrooll, S. J. (1965). The Job (s) of Management. A Journal of Economy and Society, 97-110. https://doi.org/https://doi.org/10.1111/j.1468232X.1965.tb00922.x

NurAzizah. (2014). Pengaruh Karakteristik Informasi Sistem Akuntansi Manajemen dan Desentralisasi terhadap Kinerja Manajerial dengan Ketidakpastian Lingkungan Sebagai Variabel Moderating pada Rumah Sakit di Wilayah Kota Medan. https://doi.org/10.1007/s13398-014-0173-7.2

Pasaribu, H. (2009). Pengaruh Komitmen, Persepsi dan Penerapan Pilar Dasar TQM Terhadap Kinerja Manajerial. Jurnal Akuntansi Dan Keuangan Indonesia, 6(2), 193-220. https://doi.org/http://dx.doi.org/10.21002/jaki.20 09.10

Patarianto, P. (2015). Analisa Kualitas Layanan terhadap Kepuasan Nasabah di PT. Bank Mandiri (Persero) Tbk. Cabang Sidoarjo Gedangan. MAKSIPRENEUR, IV, 28-37.

Paylosa, F. (2014). Pengaruh Strategi Bisnis dan Desentralisasi terhadap Hubungan Antara Pemanfaatan Informasi Sistem Akuntansi Manajemen dan Kinerja Manajerial. Jurnal Akuntansi FE Universitas Negeri Padang, 2(No. 1).

Putri, L. K. (2014). Pengaruh Ketidakpastian Lingkungan dan Strategi Bisnis terhadap Kinerja Manajerial dengan Karakteristik Sistem Akuntansi Manajemen sebagai Variabel Intervening. Jurnal WRA, 2(2), 475-490.

Santoso, Y. K., \& Gudono. (2007). Pengaruh 
Intensitas Kompetisi Pasar terhadap Hubungan Antara Penggunaan Informasi Sistem Akuntansi Managemen dan Kinerja Unit Bisnis dan Kepuasan Kerja. Simposium Nasional Akuntansi $X, 12,1-32$.

Sari, N. (2014). Pengaruh Ketidakpastian Lingkungan terhadap Kinerja Perusahaan Melalui Karakteristik Informasi Sistem Akuntansi Manajemen sebagai Variabel Intervening. Jurnal Akuntansi FE Universitas Negeri Padang, 2(3).

Sekaran, U., \& Bougie, R. (2017a). Metode Penelitian untuk Bisnis (6 Buku 1). Jakarta: Salemba Empat.

Sekaran, U., \& Bougie, R. (2017b). Metode Penelitian untuk Bisnis (6 Buku 2). Jakarta: Salemba Empat.

Senduk, J. M., Ilat, V., \& Tirayoh, V. (2017). Pengaruh Desentralisasi, Strategi Bisnis dan Pemanfaatan Informasi Sistem Akuntansi Manajemen terhadap Kinerja Manajerial pada PT Bank Mandiri di Manado. Jurnal Riset Akuntansi Going Concern, 12(1), 73-82.

Setyolaksono, B. (2011). Pengaruh Desentralisasi dan Sistem Akuntansi Manajemen terhadap Kinerja Manajerial. (Studi Kasus pada Industri Es Balok di Kota Semarang). Universitas Negeri Semarang.

Singgih Herdiansyah. (2012). Pengaruh Karakteristik Informasi Sistem Akuntansi Manajemen dan Desentralisasi terhadap Kinerja Manajerial dengan Ketidakpastian Lingkungan sebagai Variabel Moderating. Universitas Diponegoro.

Sugiyono. 2015. Metode Penelitian Pendidikan

(Pendekatan Kuantitatif, Kualitatif dan R\&D). Penerbit CV. Alfabeta: Bandung.

Sulistiyanto, A. E. (2005). Pengaruh Karakteristik Informasi Sistem Manajerial dengan Desentralisasi sebagai Variabel Moderating. Universitas Katolik Soegijapranata Semarang.

Sulkiah. (2016). Pengaruh Ketidakpastian Lingkungan dan Lingkup Sistem Akuntansi Manajemen terhadap Kinerja Manajerial (Studi Empiris: Rumah Sakit di Lombok Timur). Journal Ilmiah Rinjani_Universitas Gunung Rinjani, 4.

Wuryani, E., \& Djati, S. P. (2007). Pengaruh Desentralisasi dan Karakteristik Informasi Akuntansi Manajemen terhadap Kinerja
Manajerial. Jurnal Widya Manajemen \& Akuntan, 7(2), 188-206.

Undang-Undang Nomor 28

Tahun 2009 tentangPajak Daerah dan Retribusi Daerah.

Sekaran, Uma dan Roger Bougie. (2017). Metode Penelitian untuk Bisnis Pendekatan Pengembangan-Keahlian. Edisi 6. Buku 2. Jakarta: Salemba Empat.

Sayangbati, A. (2016). Analisis Kontribusi Dan Trend Penerimaan Pajak Daerah , Retribusi Daerah Pada Pendapatan Asli Daerah Studi Pada Kabupaten Minahasa Utara Periode Tahun ( 2007-2013 ) in Local Revenue Study in Kabupaten Minahasa Utara S Period of, 16(03), 699-707. 